\title{
KovÁcs FLÓRA*
}

\section{ELIDÓZÉSEINK"*}

\author{
Kulcsszavak: észlelés, emlékezés, Dasein, intencionalitás, Unverborgenheit
}

I.

Martin Heidegger $A$ fenomenológia alapproblémái $i^{1}$ című előadáskötetében Immanuel Kant elgondolásait taglalva érzékenyen köti össze az idő és az észlelés (és e társításból adódóan is az emlékezés) kérdéskörét. Bevezeti, hogy az időiség ${ }^{2}$ nem választható el a filozófia (fôbb) problémairányától: „megmutatjuk, az időiség hogyan teszi lehetővé, hogy a létet és létezőt megkülönböztessük”3. Mindezt a munkát úgy valósítja meg Heidegger, hogy jegyzi módszertanában egy kerülő úton jár ${ }^{4}$. Az ittlét (jelenvalólét, Dasein) ${ }^{5}$ viszonyulásstruktúrája, vagyis fókuszáltan az észlelés szerkezetének prezentálása, a „megragadás”, a „szabadságadás”, a „felfedés” szemantikai mezeje mozgatja fejtegetését ${ }^{6}$. Az észlelés folyamatában a meglévő „megnyilatkozása” tűnik ki: „[a]z észlelés nem más, mint hagyni valamely meglévőt szabaddá tevő́n utunkba kerülni. [...] Az ittlét mint felfedő egzisztál. A meglévő felfedettsége az, ami annak mint utunkba kerülőnek a szabaddá tételét [Freigabe] lehetővé teszi”. ${ }^{7}$ Az ittlét (jelenvalólét) leleplezésekor a megnyitás, a feltárás kerül elő, ${ }^{8}$ megnyíltsága és a létező(k) felfedettsége egymáshoz tartozik, hiszen egzisztálásának ez a feltétele. Emellett az időiség az

* Kovács Flóra (Hódmezővásárhely,1982): irodalomtörténész, egyetemi óraadó (SZTE), PhD, szerkesztő, a tiszatájonline szerkesztője. Kortárs irodalom, irodalomelmélet, színházelmélet, komparatisztika területén közöl írásokat.

** A jelen tanulmány az NKA Alkotói támogatásának keretében valósult meg.

1 Martin Heideg ger: A fenomenológia alapproblémái. Ford. Demkó Sándor. Osiris-Gond-Cura Alapítvány, Bp., 2001.

2 Az időiséget az eredendô idővel fordítja le Heidegger, uo. 299.

3 Uo. 30. Ennek a gondolatmenetnek eleme, hogy később ezt írja: „[a]z időiség a maga részéról az általában vett lét megértésének horizontját adja”, majd „az idôiségnek az ittléthez tartozó létmegértés lehetöségfeltételének is kell lennie" = uo. 322., 339. [kiemelés a kötetben]

4 Uo. 11.

5 A fenomenológia alapproblémái-kötet fordítói szándékát megőrzöm, azonban a terminológiai zavar elkerülése miatt szükséges jegyeznem az eltéréseket.

6 Vö.: „minden viszonyulás egy valamihez való viszony, az észlelés valaminek az észlelése. Ezt a valamihez való viszonyt jelöljük meg szúkebb értelemben intendereként vagy intentióként." = Heidegger: A fenomenológia alapproblémái. i. m. 79.

7 Uo. 93. [kiemelések a kötetben].

8 Uo. 270. 
intencionalitástól nem választható $\mathrm{el}^{9}$, elvégre mint a létmegértés „támasza” önmagában képviseli a kimozdítottságot, „az eredendő önmagán-kivül’10.

Az ittlét (jelenvalólét) megnyíltságához kapcsolódnia kell az igazságnak, ahhoz pedig az elrejtettségből felfedésnek. Ezzel egy körfolyamat vehető észre: „[1]ét csak akkor van, ha megnyíltság [Erschlossenheit] van, azaz ha igazság van. Igazság azonban csak akkor van, ha egy olyan létező egzisztál, amely feltár, amely megnyílik, mégpedig olyképpen, hogy e létező létmódjához hozzátartozik a megnyitás. Egy ilyen létező mi magunk vagyunk. Az ittlét maga az igazságban egzisztál. Az ittléthez lényegszerúen hozzátartozik egy feltárt világ, és ezzel egyben önmaga feltártsága” ${ }^{11}$, „[a]z igazság a görögök számára az elrejtettségből történő kivételt, a felfedést, a leleplezést jelenti"12. Az elrejtettségből felfedés a heideggeri elgondolás visszavisszatérő eleme, $\mathrm{s}$ a görög igazságfogalom mélyét tárja fel. Ebben a szemléletben az elrejtettség és a felfedés a „működő egészhez” megegyező mértékben kötődik. Ennek rendszerét $A$ metafizika alapfogalmainak ${ }^{13}$ olvasásakor is láthatjuk. A müködésben, egzisztálásban a működésről magáról való megnyilatkozás már bennfoglaltatik ${ }^{14}$, ám Hérakleitoszból következtetve Heidegger az elrejtőzés mellett ugyancsak érve ${ }^{15}$. Az igazság mint kiragadás a rejtőzés megszüntetése, megbontásként szintén értelmezhető: „[a] görög á- $\lambda \eta \emptyset q \varepsilon ı$ szó, elrejtetlenség [Un-verborgenheit], azonban a német bűntelenség [Un-schuld], végtelenség [Un-endlichkeit] szavaknak felel meg: valami, ami nem bűnös, nem véges. Ennek megfelelően az $\alpha \dot{\lambda} \eta \dot{\vartheta \varepsilon ı \alpha}$ olyasmit jelent, ami nem elrejtett. Eszerint a görögök az igazság legbenső lényegébe valami negatívat is beleértenek, amelynek a német »un-« felel meg [illetve a magyar »-tlen«]. Az $\alpha-t$ a nyelvtudományban $\alpha$-privatívumnak nevezik. Azt fejezi ki, hogy a szóból, amely előtt áll, hiányzik valami. Az igazságban a létezőt kiragadják az elrejtettségből. Az igazságot a görögök zsákmányként értik, olyasmiként, amit ki kell ragadni az elrejtettségből egy olyan összeütközésben [Auseinandersetzung], melyben épp a píбıৎ törekszik arra, hogy elrejtőzzék. Az igazság az emberi lény legbensőbb összeütközése magával a létező egészével”. ${ }^{16}$

Egy, az éntől különböző észlelése ${ }^{17}$, megnyitása, annak elrejtettségből kiszabadítása a fenti rendszernek eleme. Egy másik észlelése önmagunk megértése felé mutat: „magunkat értjük

9 Vö.: „Az ittlét csak azért intencionális, mert lényege szerint az időiség határozza meg” = Uo. 331.

10 Uo. 330. [kiemelés a kötetben]

11 Uo. 31.

12 Uo. 270.

13 Martin Heidegger: A metafizika alapfogalmai. Ford. Aradi László és Olay Csaba, Osiris, Bp., 2004.

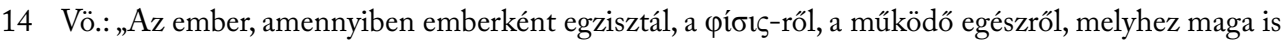
tartozik, már mindig is megnyilatkozott, méghozzá nemcsak azáltal és azért, hogy a dolgokról beszéljen, hanem emberként létezni már azt jelenti: a működőt kifejezésre juttatni. A múködő létező múködését juttatja kifejezésre, vagyis rendjét és szabályszerűségét, magának a létezőnek a törvé-

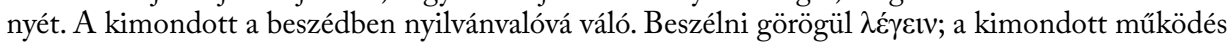

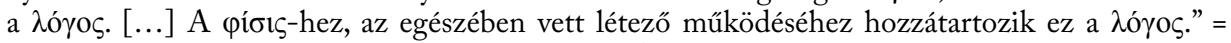
Heidegger: A metafizika alapfogalmai. i. m. Ford. Aradi László. 52.

15 Vö.: „»A dolgok múködése magától fogva törekszik arra, hogy elrejtőzzön.«” = Uo. 53.

16 Uo. 55.

17 Nem is argumentált $A$ fenomenológia alapproblémáiban Heidegger ellenvetése Nicolai Hartmann elgondolásával szemben, éppen csak említés szintjén jelenik meg. Vö.: Heidegger: A fenomenológia alapproblémái. i. m. 83 . 
meg, ám olyképpen, ahogyan nekünk nem sajátunk [nicht zu eigen], hanem ahogyan az irányuló egzisztálás mindennapiságában a dolgokba és az emberekbe belevesztünk" ${ }^{18}$. Ennek továbbviteleként értelmezhető Hans-Georg Gadamernél az elrejtetlen fogalmára utalás - a heideggeri alapokon - a barátság kapcsán: „»igaz barát«. Ezen azt értjük, hogy ő olyasvalaki, aki barátnak bizonyult, aki nemcsak látszólag mutat baráti kötődést és érzelmet. Bebizonyosodott már, hogy valódi barát, elrejtetlenül (unverborgen), mint Heidegger mondja"19. A továbbfejtés mellett ebben a gadameri érvelésben húzódik lényegi érintése az „elrejtetlen” barátságnak: egyrészt Gadamer beépíti, közelíti, sejteti a kétértelműséget, amelyet Heidegger a

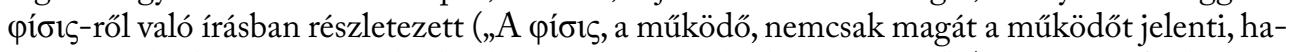
nem a működőt a maga működésében is vagy a működő müködését." $\left.{ }^{20}\right)$; másrészt Gadamer a látszólagossággal (a látszattal, a torzítással) szembeni megállapítást is mozgásba hozza („a jelenvalólétnek lényegében a már felfedetett is kifejezetten el kell sajátítania a látszattal és a torzítással szemben, és mindig újra biztosítania kell a maga számára a felfedettséget”. ${ }^{21}$ ); harmadrészt a költészet (és egyáltalában az irodalom) igazságára, „hiánytalanul mondására” összpontosít, hiszen az idézett bekezdést a fentiek után rögtön így folytatja: „[e]bben az értelemben kérdezek én a költészet igazságára"22; negyedrészt e megjegyzéssor - bár halványabban, mint az elôbbiekre - utal a barátságba beágyazva, gyaníthatóan a barátsággal nem egyezőre, $\mathrm{s}$ azon keresztül a felejtésre, majd ennek folyományaként az emlékezésre. Heidegger beszél ugyanis az elrejtetlenség-elrejtettség esetében az értetlenekről (akik feltehetőleg a barátság kontextusában nem viselhetnék a barát megnevezést, márcsak a megértés, így a feltárás hiánya miatt sem): „[a]z értetlenek előtt ellenben $\lambda \alpha v \vartheta \alpha ́ v \varepsilon ı, ~ a z ~ a m i t ~ t e s z n e k, ~ r e j t v e ~ m a r a d$,

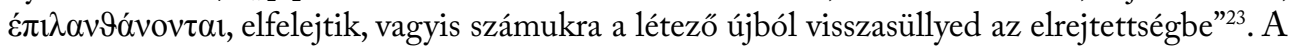
felejtés játékához lényegszerűen tartozik, hogy az ittlét (jelenvalólét) az idő eksztatikus jellegének köszönhetôen hogyan tud kimozdulni voltságához: „[m]int eljövő az ittlét volt lennitudásához, mint volt voltához, mint megjelenítő más létezőhöz mozdul ki"24.

18 Uo. 203.

19 Hans-Georg Gadamer: Miként járul hozzá a költészet az igazság kereséséhez. Ford. Tallár Ferenc = Uő: A szép aktualitása. Vál. BAcsó Béla. T-Twins, Bp., 1994. 142-157., 146.

20 Heidegger: A metafizika alapfogalmai. i.m. 57.

21 Martin Heidegger: Lét és idó. Ford. Vajda Mihály, Angyalosi Gergely, Bacsó Béla, Kardos András, Orosz István, Osiris Bp. (Második, javított kiadás), 2001.259.

A látszat, csalatkozás $A$ müalkotás eredetében is említődik, ám ott egy a létezők közötti elrejtőzésről van szó. A létező másként is mutatkozhat, ugyanakkor az egyik létező el is változtathatja a másikat. Vö.: Martin Heidegger: A múalkotás eredete. Ford. BAcsó Béla = Uő: Rejtekutak. Szerk., jegyzetek, utószó Pongrácz Tibor. Osiris, Bp., 2006. 9-70. 41.

22 Gadamer: Miként járul hozzá a költészet az igazság kereséséhez. i. m. 146.

23 HeIdegger: Lét és idő. i. m. 256.

Az emlékezés A fenomenológia alapproblémáiban egy helyen úgy jelenik meg, a „képzelet képei” mellett, mint a pszichikai észlelések egy esete. Vö.: Heidegger: A fenomenológia alapproblémái. i. m. 83.

24 Heidegger: A fenomenológia alapproblémái. i. m. 330. [kiemelés a kötetben] E rendszer hosszabb bemutatásához vö. kiemelten: uo. 328-329.

A müalkotás eredetének megőrzőkre várása és a feledés említése az elrejtés-felfedés kettősét sugalmazza, azok egybefonódását. A „megőrzőkre vonatkoztatottság” a mű igazságához tartozik, továbbá a „múködő egészre” is érdemes gondolnunk. Vö.: „Ha egyáltalán mú: mindig a megőrzőkre vonatkoztatott. Akkor is, sőt éppen akkor, ha csak vár a megőrzőkre, és megszerzi és kivárja a megőr- 
Gadamer - s a jelen elemzés - számára azért bírhat kiemelt jelentőséggel Heidegger meglátása az elrejtetlenségről, mert az a lét egészének taglalását meghatározza a műalkotás sajátosságait (is) kutatva. Heidegger $A$ múalkotás eredetében - amelyben az elrejtetlenség kérdésköre markáns -, illetve annak kiegészítésében a lét problematikájának központi státusa mellett nyilatkozik: „A múalkotás eredete tanulmány egésze tudatosan, ám kimondatlanul, a lét lényegére irányuló kérdés útját járja” ${ }^{25}$, hiszen az el-nem-rejtettség megtörténésére ${ }^{26}$ összpontosít.

II.

„Értelmetlen lenne azt kérdezni, hogyan nézett ki valójában a lépcső, melyre Dosztojevszkij »gondolt«. A költőnek sikerült az elbeszélés módja, az elbeszélói megformálás által egy imaginációt életre keltenie, mely minden olvasóban felépít valamit, méghozzá oly módon, hogy az olvasó pontosan látni véli, miként indul el a lépcső jobbra, száll alá néhány fokot, majd vész bele a sötétbe. [...] Látható ezen a példán, hogy a költố képes megidézni a nyelv önbeteljesítését."

Gadamer: Miként járul hozzá a költészet az igazság kereséséhez ${ }^{27}$

A „múködő egész” kettősségét vehetjük észre a költői szóban. Erre figyelmeztet oly nagy precizitással Gadamer, amikor „önmegtartásról” és „önmagában megállásról” nyilatkozik $A$ szó igazságáról utolsó soraiban: „[...] a szó múalkotásának esetében, ahol is az elrejtés a múvészet »képző́dményében" eleve feltételezi a nyelvben-létet és a lét bennelétét a nyelvben. A lefordíthatóság határa pontosan mutatja, hogy meddig terjed az elrejtés a szóban. Legvégső elrejtettségében ez az elrejtő. Csak aki otthon van egy nyelvben, az képes tapasztalni a költói szó önmegtartó és önmagában megálló kijelentését [...] [a költói szó - K. F.] képes visszatartani az elillanót. [...] A költői szó soha sem hagyhat fel azzal, hogy beszéddé (vagy dadogássá) váljon, hogy újra meg újra kijátssza értelemlehetőségeit." ${ }^{28}$ Az értelemlehetőségek kijátszásában az ismételt visszatartás, vagyis egy-egy interpretációs út is megmutatkozhat. Gadamer a heideggeri rendszer kettőségének „örökségét” írhatja le ezzel párhuzamban: „[a] megvonásban is van adakozás (Gewährung)"29.

Az elrejtetlenség „kimondáshoz” párosulásait állapítja meg a teoretikus: „,[m]ert mindig a kimondás szavaival van ez a szó összekapcsolva. Az elrejtetlenség annyit jelent: mondani, amit az ember gondol. [...] Az igaz-létnek ez az első értelme azt jelenti tehát, hogy az ember az

zők betérését igazságába. Sőt a feledés, amelybe a mű belemerülhet, sem semmi; még ez is megőrzés. A feledés a múből él.", in: Heidegger: A múalkotás eredete. i. m. 53.

25 Uo. 67.

26 Uo. 43.

27 Gadamer: Miként járul hozzá a költészet az igazság kereséséhez. i. m. 150-151.

28 Hans-Geog Gadamer: $A$ szó igazságáról. Ford. Poprády Judit. = Uő: $A$ szép aktualitása. i. $m$. 111-142., 140.

29 Hans-Georg Gadamer: Az „eminens” szöveg és igazsága . Ford. TAllár Ferenc. = Uő: A szép aktualitása. i. m. 188-202., 201. 
igazat mondja, azaz azt mondja, amit gondol. Ez a jelentés kiegészül azonban, különösen a filozófiai nyelvhasználatban, azzal a másik jelentéssel is, hogy egy dolog azt »mondja « magáról, ami. Igaz az, ami annak mutatja magát, ami”. ${ }^{30}$ A mondás határáig kísérésről van szó, amelyet a költészetben az alapítás tettével feletethetünk meg. ${ }^{31} \mathrm{~A}$ heideggeri elgondolás nyelvhez kötöttsége kiindulópont $A$ szó igazságáról szerzője számára. ${ }^{32} \mathrm{Az}$ összefüggéshálóban - $\mathrm{s}$ mintegy az ellentétezést prezentáló struktúrában, amely valójában a kiegészítéshez közeli múveletet rejti - lényegi mozzanat a hallgatás és megszólalás kettőse, amely a heideggeri alapozással a szorongásban gyökerezik: ,a korai Heidegger »szorongásra kész elhatározottság«-nak nevezett, ami nemcsak hallgatás, hanem a hallgatás megszakítása is, azaz szó" ${ }^{33}$. Az igazság fogalma ehhez viszonyítva kerül ebben a szövegben elő, és egy sajátos kívüliséget sejtet: „[d]e miként az igazság lényege a jelenvalólétnek az önmagát valamihez tartásból és inzisztenciából kiindulva a »titokra" és abszolút elrejtettségére egy mindig mint másra vonatkozott, akként a szó és a nyelv is bár vonatkozhatott a hallásra és a hallgatásra, azonban ami ebben »igaz« volt és ami itt »előtűnt «, éppen az egzisztencia volt, a létére a semmi előtt váró jelenvalólét” 34 . A nyelv születésének pillanatához kötődés idéződik fel. A színlelést és a hamisat faggató kérdéssorok (is) a megszólalás felé, irodalmi korpuszra (is) applikálva a ki-mondásra összpontosulnak: „[k]ellőképpen meglepő, hogy nemcsak hogy a beszélni és színlelni, sőt hazudni is tudó lény ki tud tűnni az „aletheia” révén, hanem hogy egy létező mint olyan is lehet „igazi”, mint az arany" 35 .

Egy szépirodalmi müben a fentiek megjelenítődhetnek; a leképezés elkerülése, annak meg nem valósulása, vagyis a „szépirodalmiság” megteremtődése, a költői szó megalapítása a tét.

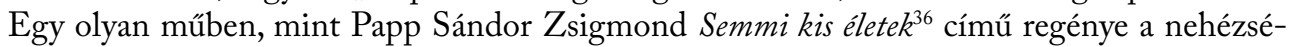
get az adja, hogy a referenciális jegyek keresését az olvasó valamilyen fokon függessze fel, azaz értelmezése ne álljon meg az előző korszak Romániája attribútumainak kutatásánál. Ehhez természetszerúleg az szükséges, hogy maga a szépirodalmi mű se redukálja magát azok bemutatására. ${ }^{37} \mathrm{Az}$ „értelemkereséshez” tartozó „,közvetítést” nem zárjuk ki: „[a] közvetítés - amely-

30 Gadamer: Miként járul hozzá a költészet az igazság kereséséhez. i. m. 146.

31 Vö.: Gadamer: A szó igazságáról. i. m. kiemelten 119., 136-137.

32 Vö.: „nemcsak, hogy maga otthon van a nyelvben [az ember - K. F.], hanem hogy a nyelvben, amit egymással beszélünk, jelen van a »lét «" Uo. 115 .

33 Uo. 114.

34 Uo. 115.

35 Uo. 113.

Nem felejthető el, hogy a gadameri rendszerben az ,igazságot” és az „autentikus dokumentum” fogalmát semmiképpen sem a „leképezés” jellemzi. Vö.: Gadamer: Az „eminens” szöveg és igazsága. i. $m$.

36 PApr Sándor Zsigmond: Semmi kis életek. Libri, Bp., 2011.

37 Vö.: „A »költő́i szabadság« fogalmával válik ez teljesen világossá. Ezt a szabadságot mindenképpen meg kell védeni, ahol történelmi eseményeket vagy személyeket érintő egyértelmú vonatkozás van jelen. Az fejeződik ki ebben, ami általában érvényes: a költő szabad. A szöveg rangját az irodalmi minőség mértéke határozza meg, mely a szöveghez mint műalkotáshoz járul. Ennek nem felel meg semmiféle közvetlen referencia. Kétséget kizáróan érvénytelennek tekintjük a költői tartalmakkal és azok költészeten kívüli jelentésével kapcsolatos önálló, idegen érdekeltséget.” = GaDAMER: $A z$ „eminens” szöveg és igazsága. i. m. 197. A történész szempontjainak különbsége húzható itt alá. Vö.: még: Gadamer: A szó igazságáról. i. m.134-135. 
nek fogalmába beleértődik mindenfajta szöveg- és műértelmezés, az irodalom- és mûvészetkutatás minden változata - mint az egykor és a most horizontjának találkozása a mú megszólító ereje indíttatására: értelemkeresés, és mint ilyen, igazságtörténés" ${ }^{38}$. A közvetítettség és a belevetettség állapotát jegyzi Rigán Lóránd is Heidegger-fejtegetésében ${ }^{39}$, amelynek egy adott passzusában a horizont és az elrejtés problematikája olvasható: „[a]hhoz azonban, hogy az összevetést egyáltalán elvégezhessük, a világnak előbb fel kell tárulnia tapasztalatunkban. Sőt meg kell jelennie benne már ahhoz, hogy bármiféle kijelentést tegyünk róla. Ez a megjelenés azonban mindig elrejtést is jelent. Az illető látásmód szükségképpen elrejti mindazt, ami egy másikban feltárulhatna. Ennélfogva, mivel nem feltételezhetjük, hogy a jelenlegi, történetileg meghatározott látásmódunk az egyedül lehetséges, el kell ismernünk, hogy mindaz, ami van, egészen másként is megmutatkozhatna számunkra, ha egy másik horizontba helyezkednénk. Ezek közül a horizontok közül egyik se kizárólagosan érvényes, de a maga módján mindegyikük végső, mert az illető kultúra számára a lét értelmének éppen aktuális határait vonja meg. A végső értelem azonban titokban marad”. ${ }^{40}$

Az idézett Érték és történelem-kötetben a feltárultságot (így az elrejtettség-elrejtetlenség problémakörét) a lelkiismerettel összefüggésben tárgyalja Egyed Péter. Számunkra itt a lelkiismeret, az ítélet kérdése kevésbé, sokkal inkább a jelenvalólét önmaga előtti feltárultsága a fontos, ily módon önmaga meghallása: ,a lelkiismeretnek csak akkor lesz hangja, ha immár a jelenvalólét feltárultságában mutatkozik meg. Ha pedig megnevezzük a létezőnek azt az alapszerkezetét, amelynek az egzisztenciáléi a diszpozició, a megértés, a hanyatlás és a beszéd, akkor a lelkiismeretről ki fog derülni, hogy az hivás, beszédmódusz". ${ }^{41}$ A lelkiismerethez kötött müködési módban nagy jelentősége van a tanúskodásnak, amelyet a jelenvalólét önmaga ellen vagy mellett hajt végre, és amely rendszerbeli beépítése miatt oly rigorózusnak vélhető a kanti kötelességelemzés. ${ }^{42}$ A tanúskodáshoz viszont szükséges a lelkiismeret időszerkezetének sa-

Heideggeri-gadameri gondolatiságú interpretáció ehhez kapcsolható differenciáltságot ír le: „Van Gogh parasztcipőket ábrázoló festménye létrangját tekintve nem másodlagos, nem kevésbé »valóságos«, mint a »modell«, aminek a felhasználásával a kép elkészült, ellenkezőleg, az ábrázolás révén megmutat valamit annak rejtekező lényegéből, illetve - ahogyan Gadamer fogalmaz - fölemeli a létezőt »létének felfokozott igazságába«" = ORBÁN Gyöngyi: Igazságtörténés. Korunk, 2008 december, http://www.korunk.org/?q=node/8\&ev=2008\&honap=12\&cikk=9402, elérés: 2013. szeptember 8.

38 Orвán: Igazságtörténés. i.m.

39 „a személyes tulajdonképpeniség értéktartalma, »az élet értelme a Lét és idóben olyasvalami lesz, amit nem mi magunk választunk, hanem amire a történelmi örökség és a jelenlegi fakticitás hermeneutikai közvetítése folytán rábukkanunk, ami »adódik“”, in Rigán Lóránd: Vajon nem zuhanunk-e szakadatlan? Nietzsche, Heidegger, Camus = Érték és történelem. Szerk. Egyed Péter. ProPhilosophia, Kolozsvár, 2008. 239-279., 268.

40 Uo. 271. Érdemes e taglalást összevetni a 21. lábjegyzetben vizsgált, $A$ múalkotás eredetének adott egységével.

41 EgYed Péter: A modernitás értékszemléletének a felbomlása = Érték és történelem. i. m. 153-183., 178. Nehéz a vizsgált területen a „határállítás”, hiszen „[a] jelenvalólét létjellemzői, az egzisztenciálék egyszerre ontológiaiak és etikaiak, bár Heidegger ontológiai "fundamentalizmusánál « fogva a kifejezést »elsődleges ontológiai jelentésében « rögzíti"= RIGÁN: i. m. 268.

Vö.: EGyed: A modernitás értékszemléletének a felbomlása. i. m. 157-158. 
játosságait tudni, azaz a visszaemlékezés folyamatát adottnak venni ${ }^{43}$, amelyben pedig a töredezettség és az „átteremtés” ${ }^{44}$ érvénnyel bír. Nem véletlen, hogy ebben a kontextusban a sokat tárgyalt gadameri emlékezéselmélet a benne foglalt átírásra összpontosítással eszünkbe ötlik. ${ }^{45}$

III.

„Az emlékezni nem akarás és a felejteni nem tudás kettősége, ellentéte talán a legsúlyosabb tapasztalata a regénynek."

Boka László: Történelem - alulnézetböllt

Boka László Semmi kis életek-könyvről írt kritikájából nem a kettősség megfogalmazása okán került be részlet mottóként, hanem sokkal inkább azért, mert jól összefoglalja az e regényben lévő mechanizmust. Bányai Éva szintén az emlékezést húzza alá e könyvről szóló tanulmányában, ám ő a Gadamer révén is taglalt emlékezésátírást hangsúlyozza. ${ }^{47} \mathrm{Ez}$ utóbbi szöveg egy olyan megállapítást tartalmaz, amely kardinálisnak mondható, hiszen az elmesélés-elmesélhetetlenség kérdéskörét pozícionálja: „a romániai (tágabban: kelet-európai) diktatúra és az átmenet, fordulat leírásának, elmondásának a lehetetlenségére irányítj[ák] a figyelmet”88. Ez a lehetetlenség talán az, ami a Semmi kis életeket a Boka révén is célzott bủnügyi regény közelébe lendíti ${ }^{49}$.

A jelenvalólét feltárultsága, megnyitása önmaga előtt az említett elmesélhetetlenségre/elmondhatatlanságra íródik rá. Amikor az apa vállalja, hogy jelentéseket fog készíteni környezetéről, akkor azt azért teszi, hogy a határátlépést megkísérlő fiát - aki feltehetőleg a szökési kísérlet vagy a vallatás közben halt meg - eltemethesse. A lelkiismeret múködési módja, a

43 Vö.: uo. 156.

44 Visszatérő szóhasználat vagy rájátszó fejtegetés a teremtéssel összefüggésben Nietzschénél és ebből adódóan az ő gondolatiságát vizsgáló Rigánnál. Vö.: Rigán: i. m. 245., 247., 249.

45 Vö.: Hans-Georg Gadamer: Költeni és gondolkodni Hölderlin Emlékezés címú verse tükrében. Ford. Orosz Magdolna = Uő: A szép aktualitása. i. m. 202-227.

46 Boкa László: Történelem - alulnézetböl. Papp Sándor Zsigmond nagyregényéröl = Uő: Egyszólamú kánon?, Gondolat, Bp., 2012. 260-278., 275.

47 BÁNYAi Éva: Semmi kis életek: átmenetnarratívák geokulturális kontextusban. Kézirat [megjelenés előtt]. Köszönet Bányai Évának, hogy a kéziratot rendelkezésemre bocsátotta. [Majd: Kulturális identitás és alteritás az idöben. Szerk. Pieldner Judit, PAp Levente, TApodi Zsuzsa, Forisen Péter és PApP Klára. Debreceni Egyetem Történelmi Intézet, Debrecen, 2013. (Speculum Historiae Debreceniense 16.) 323-331.]

48 Uo. 325-326.

A traumatikus történések elbeszélése kapcsán bőségében nyilatkozik erről a kérdésről Bolgár Dániel $A$ fost sau n-a fost? (Volt-e vagy sem? Corneliu Porumboiv, 2006, http://www.youtube.com/ watch?v=rOCqYnM_iIo, elérés: 2013. szeptember 15.) címú film és Gross Szomszédok-mûve vonatkozásában. Vö.: Bolgár Dániel: A múlttal végképp szembenézni? Traumatikus történés és történelmi elbeszélés = Esemény - trauma - nyilvánosság. Szerk. DánéL Mónika-Fodor Péter-L. VARga Péter. Ráció, Bp., 2012. 134-149.

49 Bока: i. m. 262., 272. 
hozzá kötődő előtt és után időbelisége figyelhető meg, hiszen a jelentések megírásának tette esetében csak utólag lehet érvelni, még akkor is, ha az elött és után által zárt időtartam rövid. Itt két fontos aspektust kell említeni: egyfelől ha a fiú nem halt meg, s a vele szökni próbáló Eszter helyesen ismeri fel ${ }^{50}$, akkor hiábavaló volt a jelentések alkujába lépés ${ }^{51}$. Másfelől a narrátor azt sulykolja, hogy a férfi az anya, vagyis a felesége miatt lép az alkuba, hiszen hogyan is tudná vele megértetni, hogy a fiukat még el sem temethetik. ${ }^{52} \mathrm{E}$ logikánál a lelkiismeret mozgásába kerül egy másik, egy harmadik individuumhoz kapcsolt felelősség.

A feltárultság kérdése a jelentések írása során élesen vetődik fel. Az emlékezés precizitásába vetett naiv hittel szövődik egybe, illetve nem feltétlenül a jelentést létrehozó feltárultságát mutatja, hanem a jelentést író előtti feltárultságot. Mindez egy olyan múben lelhető fel, amelyben a hazugság, elfedés a benne tematikus elemként meghúzódó rendszer sajátja. Ennek értelmében a hazugság és az elfedés feltárultságával szintén számolni kell.

A narrátor a jelentéseket író Rudolfnál azok írása közben a térből és az időből kiemeltséget, vagy legalábbis az idő és tér megmásítódását, és Rudolfnak a körülötte lévő egyénekétől elválását diagnosztizálhatja, s egyben a környezet tere minimális szeletének „uralását”(„Ahogy a ceruza finom hersegése megállt, felerősödtek az udvari zajok.” ${ }^{53}$; „Hiába volt ez a legszűkebb helye a lakásnak, itt még uralni tudta a karnyújtásnyi teret”的). A környezet terétől elválás az írás teréhez kötődés miatt jön létre. Rudolf a jelentések produkálása során az emlékek áradását tapasztalja, ennek kontrolálását eltartja magától. Egyrészt az írás természetéhez párosítja az emlékáradatot, másrészt majd a jelentéseket olvasókra hárítja a „szemezgetést”, harmadrészt az emlékezéshez tartozó felelősséget áttestálja. Számára az írás egyre inkább a feloldozáshoz ${ }^{55}$ kapcsolódik, a traumát átélt traumától megszabadításához, a kiírásához, amely a dühöt szintén tartalmazhatja. ${ }^{56}$ A jelentések létrehozásának kezdetén a személyek tárgyia-

50 Vö.: PAPp: Semmi kis életek. i. m. 358. Ennek erős elbizonytalanítása található a 389. oldalon.

51 Ehhez a következtetéshez párosul a Boka által felvillantott megrendító, a szereplők nézőpontjából végzetesnek nevezhetô, a maguknak sem bevallott logikai sor: „Ahol bizonyosság soha sincs. Ezt a Balázs meggyilkolását követően a diktatórikus rendszert váltó évek sem képesek felülírni: súlyos terhüket a mindennapok hordozzák, hiszen a fiú lebegtetett, remélt és egyszerre félelmetes feltünésének, túlélésének lehetősége, őrülete hangsúlyos allegóriája az egész kötetnek. A reményt élteti, hogy mindez nem is történt meg, nem is volt talán igaz...”, in: BокA: i. m. 277.

A tett feleslegességének kierőszakolása olvasható onnan is, hogy a jelentéseket kieszközlő szervek mindent tudtak a jelentések megírása előtt. Vö: Cs. Gyimesi Éva emlékére. Kolozsvári Rádió, 2011. 06.01.,http://www.radiocluj.ro/hu/multimedia/hangtar/reszletek/audio/cs-gyimesi-eva-emlekere. html, 27:27-28:15, 2013.10. 07.

52 Ezzel ellentétes irányt nem tisztáz a narrátor, hiszen csak egyszer történik célzás arra, hogy talán az anyát is bevihetik a tisztek vallomás miatt. Vita olvasható, hogy érdemes-e. Az anyáért kiszállók elindulnak, e száltovábbvezetés azonban elmarad. Vö.: PAPP: Semmi kis életek. i. m. 239-240.

53 Uo. 22.

54 Uo. 15.

55 E regényben a teológiai diskurzus nem jelenik meg a nyelvhasználatban.

56 „Az emlékeket, ahogy végül egymásba kapaszkodnak a sorok között, mintha mindig is a rend parancsolt volna nekik. Pedig válogatás nélkül rögzített mindent. Mindent, ami eléje került. Úgy érezte, nem az ő feladata a mérlegelés, az egyes részletek kiemelése. Az írás magának vájt medret, ő csupán követte engedelmesen.”; „Hogy ilyesmi is kisarjadhat az ő kordában tartott lényéből, miközben épp az írás vette el - minden oldallal jobban és jobban - a harag ízét, és nyugtatta meg fokozato- 
sítását figyelte meg a férfi, ehhez párosult a bosszú s a feleség védelme. ${ }^{57} \mathrm{~A}$ lelkiismeret - mely egyfelől a munka precizitásához, másfelől a jelentésekben szereplők sorsához társul - azonban újra és újra feltűnik. E kettő mintha kizárná egymást, hiszen ez írástípushoz köthető pontosság határozottan a benne feltűnők elveszejtését hozhatja magával. Éppen ezért segítette Rudolfot a tárgyiasítás, továbbá egy olyan fajta eltávolítás, amely szépirodalmi mű teremtéséhez hasonlítható, annak írása előtti, közbeni állapotot sejtet ${ }^{58}$.

A feltárultság kérdéskörénél lényeges, hogy Rudolf a tiszt Nicu Zmeura hozzá való viszonyulásában a barátság lehetőségét felvillantja, még akkor is, ha az csak egy másik (politikai) rendszer esetében valósulhatna meg: „[h]irtelen közel érezte magához a tisztet. Ahogy vezeklő a gyóntatóját, bűnös a messziről jött megmentőjét. Mert éppen ez volt a legfurcsább az egészben. Ha jobban belegondol, akár a legjobb barátja is lehetne ez a szénszemű ember, hiszen mindent tud róla. Még ha az a minden néha nem több mint ami egy dossziéba beleférne. De másutt, egy talán egészségesebb világban ez egy egész életre elég lenne. Számon tartanák egymás névnapjait, együtt járnának meccsre vagy horgászni a bányatóhoz, és közös történeteik lennének, ha unalmasak, ha kiszámíthatóak is. De hát az unalom is olyan, mint a szerelem, csak akkor kezdjük értékelni, ha végképp elpárologott. Zmeura ismerte ôt a legjobban, és ehhez nem kellett egyéb, minthogy figyelmesen elolvassa a jelentéseit, némi türelemmel egymáshoz illessze a túlburjánzó részleteket" ${ }^{59}$ A jelentések olvasásának módszerében az elhajlások, így az információ keresése rejlik, azaz a felügyelet eszközeinek ${ }^{60}$ aktiválása. Emellett tűnik fel, ezzel összefüggésben jelenik meg az az olvasási mód, amely a feltárultságból adódik. A narrátor természetesen Rudolf és Zmeura hosszas, italozással egybekötött beszélgetéseinek kiegészítő funkcióját sem hanyagolhatja el. A „felderengő” elrejtetlenség nem egyezik meg a fiúk (Roland, Précsek és Lajoska) barátsága kapcsán említhetővel. Valójában Rudolf és Zmeura barátságának a célja maga az elrejtetlenség, vagyis nem a „valódi barát” lét, az „elrejtetlenül” megjelenő barátság, hanem az elrejtetlen elrejtetlenség, s ehhez - csakúgy, mint a barátsághoz - szkeptikusan és éllel viszonyulnak:

”- De miért kérdezősködjek?

- Mert az ember csak igaz történetekkel szerezhet barátokat.

- Barátokat? Miféle barátokat?

- Ma mindent a szájába kell rágni?! - nézett rá dühösen Zmeura. Majd felpattant, és járkálni kezdett a szobában. - Azt gondolom, maga is belátja, hogy ez nem tarthat örökké.

- Micsoda?

- Hát ez az egész! - mutatott körbe az üres szobában. - Nem azt mondom, hogy holnap vagy holnapután, de öt vagy tíz év múlva egyszer csak összedől. És mi még akkor is élni fogunk". ${ }^{61}$

san. Írni, jegyezte le az első hónap végén, annyi mint feloldozni önmagunk, és másokra ruházni az emlékezés terheit." = PAPP: Semmi kis életek. i. m. 15.; 49.

57 Uo. 61., 80-81.

58 Uo. 14.

59 Uo. 117.

60 Vö.: Michel Foucault: Felügyelet és büntetés. Ford. Fázsy Anikó. Bp., Gondolat, 1990; Georges Banu: A felügyelt szinpad. Ford. Koros Fenete Sándor. Koinónia, Kolozsvár, 2007.

61 Papp: Semmikis életek. i. m. 119. 
Papp még egy vonással gazdagítja a kérdéssort: az ,igaz történetével”. Zmeurának szükséges, hogy el tudja mondani Rudolf számára a férfi fiának ,igaz történetét”, hiszen majd Rudolf ezzel az elrejtetlenséget bíró történettel szerezhet „valódi barátot”. Ez pedig hasznára lehet még Zmeurának, a tisztnek a rendszer felbomlása után.

Roland, Précsek és Lajoska barátsága „valódi barátság”, amelynek az elrejtetlenség elemi egysége. A fiúk a hozzá kötődő feltárultsággal kapcsolódnak az igazsághoz, vagyis az elrejtetlenség él, ám ez abban is igazolódik, hogy nincs szükség a verbalizálásra: „[m]ert egy dolog tudni, hogy innen elválaszthatatlan barátok, és más bevallani. Úgy tör ilyesmi az emberre, olyan váratlanul és megterhelően, mint a szerelem, amelynek minél inkább firtatja az okait az ember, annál kevésbé érti” ${ }^{62}$.

A feltárultság leírhatósága azonban egy olyan történetbe ágyazódik, amely beleütközik egy rendszer elmesélhetőségének/elmondhatóságának problematikájába; a rendszer elmesélhetôsége ellenben egy szépirodalmi produktumnak nem lehet célja, vagy legalábbis nem azok az irányai, amelyek a történelemtudomány módszertanában fogalmazódnak meg. Sokkal inkább az elmesélhetetlenség jelenik meg újra és újra részint az emlékezésnél megmutatkozó sokféleség és átírás, részint az egyén saját történetéhez való ragaszkodás és a saját történet betüremkedései ${ }^{63}$, részint a történelmi fogalmak generikus képekként való múködései ${ }^{64}$ miatt. A zene nyelvének idézése, a rá való utalás viszont az irodalmi mű nyelvének eszközeivel a Semmi kis életek esetében csak részleges sikert jelezhet, hiszen Beethoven 18. zongoraszonátájának egységei e regényben Eszter Rudolf fia utáni nyomozásaival esnek egybe, ugyanis a férfi, akinek életét meglesi a nő a Beethoven 18-ban - mely kétségtelen, hogy a Vadászat címú zongoraszonátára célzás - lakik. ${ }^{65}$ A nyelv kötöttségei túl erősek, bár a zenei egységek és a lépcsőn való futás felsejlése ${ }^{66}$ ténylegesen elindít egy párosítást, ám a megnevezés precizitása az egyértelműsítés felé terelhet.

Az elmesélés/elmondás kényszere, a belevetett hit nem szűnhet meg. Ezt sugallják Rudolf még nyolcvannégyben rótt hetenkénti levelei feleségének ${ }^{67}$, mintha már az írás lenne az egyetlen forma, amelyben e férfi a feltárultságot képes megvalósítani.

62 Uo. 146.

63 Ennek tapasztalatáról beszél Visky András is, vö.: „Én azt hittem ugyanis, meg tudom írni Anyám történetét, miközben nagyon hamar kiderült, hogy senki másnak a történetét nem tudjuk sohasem megírni, mindenki történetében csak a saját történetünket írjuk meg." = A szabadság megtapasztalásának lehetöségei. Visky Andrással Kovács Flóra beszélget. Tiszatáj, 2011. október, 16-23. 18.

64 Vö.: VIncze Hanna Orsolya: Tények és toposzok a történelemirás narrativista elméleteiben = Emlékezet és kommunikáció. Narrativák az egyéni, a társas és a közösségi identitás teremtésében. Szerk. GAGYI József. Kolozsvár, Scientia Kiadó, 2007. 57-67.

65 A blokkházra való utalás is csak a hely elbizonytalanításának funkciójával bírhat, csakúgy, mint az egyszerre fel-feltűnők Kolozsvárra, Csíkszeredára vagy akár Szatmárnémetire (ezek egy részéről Bányai Éva is nyilatkozott, vö.: BÁNYAI: $i . m$.); a Beethoven 18. kapcsán az esetlegesség és a véletlen egybeesés elvethető, jóllehet erre szövegszerű bizonyítást nem találhatunk.

66 Daniel Barenboim Beethoven 18. zongoraszonátáját játssza a Mezzo felvételén: http://www. youtube.com/watch?v=FToI2ic4OHA, elérés: 2013. október 11.

67 A levelek léte egyszer említődik, vö.: PApp: Semmi kis életek. i. m. 54. 


\section{OUR TEMPORISATIONS}

Keywords: Papp Sándor Zsigmond, memory, apperception, Dasein, Unverborgenheit

In this article I will examine Papp Sándor Zsigmond's Semmi kis életek with the help of the theoretical works of Martin Heidegger and Hans-Georg Gadamer focusing on apperception, intentionality and Dasein.

\section{TEMPORIZĂRILE NOASTRE}

Cuvinte-cheie: Papp Sándor Zsigmond, amintire, percepţie, Dasein, Unverborgenheit

În articol se abordează opera Semmi kis életek de Papp Sándor Zsigmond folosind scrierile teoretice ale lui Martin Heidegger și Hans-Georg Gadamer cu accente pe percepţie, intenţionalitate și Dasein (prezenţă). 